TITLE:

Association of novel and established polymorphisms in neuronal nicotinic acetylcholine receptors with sporadic Alzheimer's disease.(Abstract_要旨)

AUTHOR(S):

Kawamata, Jun

\title{
CITATION:
}

Kawamata, Jun. Association of novel and established polymorphisms in neuronal nicotinic acetylcholine receptors with sporadic Alzheimer's disease.. 京都大学, 2002, 博士(医学)

ISSUE DATE:

2002-03-25

URL:

http://hdl.handle.net/2433/149693

RIGHT: 


\begin{tabular}{|c|c|}
\hline 氏 & 加帮 \\
\hline 学位(専攻分野) & 士（医 \\
\hline 学 位記 番号 & 医 博 第 2463 号 \\
\hline 位授与の日付 & 平成 14 年 3 月 25 日 \\
\hline :位授与の要件 & 学位規則第 4 条第 1 項該当 \\
\hline 究科・専攻 & 医学研究科脳統御医科学系専攻 \\
\hline 位論文題目 & $\begin{array}{l}\text { Association of novel and established polymorphisms in neuronal nico- } \\
\text { tinic acetylcholine receptors with sporadic Alzheimer's disease } \\
\text { (孤発性アルツハイマー病と神経型ニコチン性アセチルコリン受容体の未報 } \\
\text { 告及既知の多型性との関連) }\end{array}$ \\
\hline
\end{tabular}

\section{論文 内容の要旨}

家族性アルツハイマー病（AD）の原因遺伝子として，現在までにアミロイド前駆体蛋白，プレセニリン 1 ・2, アポリ ポ蛋白 $\mathrm{E}$ (APOE) が同定されている。孤発性 AD については APOE 84 アレルが危険因子である以外は明かな遺伝的危険 因子は同定されていない。一方，生化学的な研究では，ADの記憶障害の説明をアセチルコリン系の障害によるとするコリ ン仮説が約25年前に発表されて以降，これを支持する in vivo 及び in vitroの膨大な研究がなされている。臨床面に㧠いて も, 現時点で有効性が認められ使用が認可されている AD 治療薬はアセチルコリンエステラーゼ阻害剤であることも, こ の仮説を強めている。また，個々の $\mathrm{AD}$ 患者に扔いてアセチルコリンエステラーゼ阻害剤による治療の反応性が異なるこ とが知られており, 遺伝的な背景が関与していることが推定されている。さらに近年，アミロイド $\beta$ がニコチン性アセチ ルコリン受容体（nAChR）の $\alpha 7$ 型と強く結合するという報告もなされるなど, アミロイド $\beta$ と $\mathrm{nAChR}$ との相互作用も 注目されている。

孤発性 $\mathrm{AD}$ 発症における神経型 $\mathrm{nAChR}$ 遺伝子の多型の関与について検討するため, 中枢神経系で多く発現している神 経型 $\mathrm{nAChR}$ の $\alpha 3,4,7, \beta 2$ の 4 つの遺伝子（CHRNA3，CHRNA4，CHRNA7，CHRNB2）について孤発性 AD 群 （58例）と対照群 (52例) で遺伝的多型の頻度などについて検討を行なった。末梢血よりDNA を抽出し, 各遺伝子のエク ソンごとに100から $200 \mathrm{bp}$ の長さにPCR にて増幅し SSCP 法を用い多型性のスクリーニングを行った。既知の多型の確認 を行い，各遺伝子について幾つかの未報告の多型を見出した。確認されたこれらの多型につき，両群に拉けるアレル頻度の 差を $\chi^{2}$ 検定または Fisherの直接確率法を用い解析を行った結果, CHRNA3 と CHRNA4 遺伝子のアミノ酸置換を伴わな い特定の多型群のアレル頻度が, $\mathrm{AD}$ 群と対照群で統計的に有意に差を示した。 $\mathrm{AD}$ 群と対照群をさらに APOE $\varepsilon 4$ アレル の有無によってグループを分けて検討したところ, APOE $\varepsilon 4$ のアレルを含まない群での比較でも有意差を示した。APOE $\varepsilon 4$ のアレルをもつ群でも同様の分布傾向を示したが, 有意差は示さなかった。これらのアレル頻度の差は, APOE $\varepsilon 4$ アレ ルの有無に関係無く認められ，独立した危険因子であると推定された。

また, $\mathrm{AD}$ 患者一例に CHRNA4 遺伝子のミスセンス変異 (Ser413Leu), さらにもう一例の AD 患者にも CHRNB2 遺伝 子のミスセンス変異 (Gln397Pro) を認めた。これらのアミノ酸は共に哺乳類では保存されているが, M3 と M4 の間にあ る種によって多様性の高い細胞質側ループ領域に位置していた。CHRNA4 と CHRNB2 遺伝子は共に常染色体優性遺伝性 夜間前頭葉てんかんの原因遺伝子としても知られ，大規模なスクリーニングが行われているが，今回認めた細胞質側ループ 領域のアミノ酸置換は報告されていない。

以上の検討から, 神経型 $\mathrm{nAChR}$ 遺伝子多型が APOE 多型とは独立して孤発性 AD の発症に関連している可能性が示唆 された。 


\section{論 文 審査 の 結 果 の 要 旨}

孤発性アルッハイマー病（AD）発症に扔ける神経型ニコチン性アセチルコリン受容体（nAChR）遺伝子の多型の関与 を検討するため，中枢神経系で発現している神経型 nAChRの 4 つの遺伝子 (CHRNA3，CHRNA4, dHRNA7, CHRNB2）について，孤発性 AD 群（58例）と対照群（52例）で遺伝子多型の頻度を検討した。既知の多型の確認を行う と共に, single-strand conformational polymorphism 法を用いて多型のスクリーニングを行い, 各遺伝子でいくつかの未 報告の多型を見出した。これらの多型の両群に抢けるアレル頻度を $\chi^{2}$ 検定を用いて解析した結果, CHRNA3 と CHRNA4 遺伝子の特定の多型群のアレル頻度に而群間で有意な差を認めた。このアレル頻度の差はAPOE 84 .アレルの有無に関係無 く認められた。

また, AD 患者一例に CHRNA4 遺伝子のミスセンス変異（Ser413Leu），他の一例にCHRNB2 遺伝子のミスセンス変異 （Gln397Pro）を認めた。これらの変異は, nAChRの3，4番目の膜貫通領域間の細胞質側ループ領域に位置していた。

以上の検討から, 神経型 $\mathrm{nAChR}$ 遺伝子多型が, 孤発性 $\mathrm{AD}$ の発症に関して, APOE 多型とは独立した危険因子である 可能性が示唆された。

以上の研究は, 孤発性 $\mathrm{AD}$ の発症と神経型 $\mathrm{nAChR}$ 多型の関連性の解明に貢献し, $\mathrm{AD}$ の予防法・治療法の開発に寄与す るところが多い。

したがって，本論文は博士（医学）の学位論文として価値あるものと認める。

なお，本学位授与申請者は，平成14年 2 月 6 日実施の論文内容とそれに関連した試問を受け，合格と認められたものであ る。 